\title{
Body dimension comparisons between slick and wild type-haired Puerto Rican Holsteins ${ }^{1,2}$
}

\author{
Héctor L. Sánchez-Rodríguez ${ }^{3}$ \\ J. Agric. Univ. P.R. 103(1):59-68 (2019)
}

\begin{abstract}
A previous study from our group evaluating growth in dairy heifers suggests that Puerto Rican Holstein slick-haired heifers (SLICK) could reach maturity earlier and at smaller body size than their wild type-haired (WT) counterparts. Thus, the present study aimed to determine if such differences exist in mature cows by comparing several body dimensions (i.e., body weight, withers height, hip height, thoracic perimeter, barrel, and shoulder to pin bone distance) of 24 SLICK and 54 WT lactating Holstein cows at the Agricultural Experiment Station in Lajas, Puerto Rico. Also, body weight was divided by each dimension to obtain the respective ratios. Data were analyzed by the GLIMMIX procedure of SAS. The SLICK cows presented larger barrels $(236.54 \pm 2.68$ vs. $231.06 \pm 2.29$ $\mathrm{cm} ; \mathrm{P}=0.0363)$ and body weight / shoulder to pin bone distance $(3.51 \pm 0.09 \mathrm{vs}$. $3.32 \pm 0.08 \mathrm{~kg} / \mathrm{cm} ; P=0.0218$ ) than their WT counterparts. However, the shoulder to pin bone distance was smaller in SLICK than in WT cows $(180.07 \pm 1.82$ vs. $185.20 \pm 1.56 \mathrm{~cm} ; P=0.0059)$. No significant differences between hair coat groups were observed in any other evaluated variable. The SLICK cows had shorter and deeper bodies than WT cows. Future studies should evaluate if such differences could impact their productive efficiencies.
\end{abstract}

Key words: slick-haired Holstein cows, body weight, body dimensions

\section{RESUMEN}

Comparación de dimensiones corporales de vacas Holstein puertorriqueñas pelonas y regulares

Un estudio previo de nuestro grupo evaluando el crecimiento en novillas sugiere que las novillas Holstein puertorriqueñas de pelo corto (PELONAS) podrían madurar más temprano y con un menor tamaño corporal que novillas similares de pelo regular (REGULARES). El presente estudio fue dirigido a evaluar si estas diferencias existen en vacas maduras, mediante la comparación de diferentes dimensiones corporales (i.e., peso corporal, altura a la cruz, altura a la cadera, perímetro torácico, barril y distancia entre el hombro y la punta del anca) entre 24 vacas Holstein PELONAS y 54 REGULARES de la Estación Experimental Agrícola en Lajas, Puerto Rico. Además, el peso corporal fue dividido sobre cada dimensión para

${ }^{1}$ Manuscript submitted to Editorial Board 21 September 2018.

${ }^{2}$ The author thanks Gabriela Soriano-Varela, Melvin Mercado-Ayala, Eduardo Matos-Padilla, Gladycia Muñiz-Colón, and Katherine Domenech-Pérez for their valuable help with data collection and manuscript proofing.

${ }^{3}$ Associate Professor, Animal Science Department, University of Puerto Rico at Mayagüez. 


\begin{abstract}
obtener las respectivas relaciones. Los datos se analizaron mediante el procedimiento GLIMMIX en SAS. Las vacas PELONAS presentaron mayores barriles $(236.54 \pm 2.68 \mathrm{vs} .231 .06 \pm 2.29 \mathrm{~cm} ; \mathrm{P}=0.0363)$ y relación peso corporal / distancia entre el hombro y la punta del anca $(3.51 \pm 0.09$ vs. $3.32 \pm 0.08 \mathrm{~kg} /$ $\mathrm{cm} ; \mathrm{P}=0.0218$ ) que las vacas REGULARES. Sin embargo, la distancia entre el hombro y la punta del anca resultó menor en las vacas PELONAS que en las vacas REGULARES $(180.07 \pm 1.82$ vs. $185.20 \pm 1.56 \mathrm{~cm} ; \mathrm{P}=0.0059)$. No se observaron diferencias significativas entre grupos de pelaje en las demás variables evaluadas. Las vacas PELONAS presentaron cuerpos más cortos y profundos que las vacas REGULARES. Estudios futuros deben evaluar si la eficiencia productiva puede ser afectada por estas diferencias.
\end{abstract}

Palabras clave: vacas Holstein de pelo corto, peso corporal, dimensiones corporales

\title{
INTRODUCTION
}

Puerto Rico's dairy industry exclusively uses temperate Bos taurus cattle breeds (Sánchez, 2018), which are highly susceptible to heat stress (Silanikove, 2000). These animals are normally longhaired (wild type-haired; WT). Fortunately, a short-haired phenotype (SLICK), highly adaptive to the local tropical climate, also exists in the major dairy breeds in Puerto Rico. Due to the negative impact that heat stress exerts on the productivity of temperate Bos taurus cattle (West, 2003), SLICK cattle received considerable scientific attention in recent years because of its superior thermoregulatory capacity. Studies have determined that, when exposed to heat stress, mature SLICK cows maintain lower body temperatures (Sánchez-Rodríguez et al., 2016) and respiration rates (Castro et al., 2015), have larger sweat glands (Contreras-Correa et al., 2017; Muñiz-Cruz et al., 2018) and higher milk production values (Contreras-Correa et al., 2016).

In a recent study from our group (Muñiz-Cruz et al., 2017) we observed differences between the growth trends of SLICK and WT Puerto Rican Holstein heifers from four to 34 months of age, suggesting that the first group reaches maturity earlier and with a smaller body size. This may be an important finding because studies of WT Holstein cattle from Minnesota have associated a smaller body size with superior productive efficiency, relative to similar large sized animals (Mahoney et al., 1986; Yerex et al., 1988; Hansen et al., 1999). To this author's understanding, however, body size-related comparisons between mature SLICK and WT cows in Puerto Rico are not available in literature. Thus, the current study aimed to determine if such differences in body dimensions in fact exist between mature SLICK and WT Puerto Rican Holstein cows.

\section{MATERIALS AND METHODS}

Body dimensions were compared between 24 SLICK and 54 WT lactating Puerto Rican Holstein cows from the Agricultural Experiment 
Station dairy herd in Lajas, Puerto Rico. Animals in the lactating herd were considered as mature cows. The SLICK and WT groups were balanced for milk yield $(16.78 \pm 1.16$ and $16.92 \pm 0.68 \mathrm{~kg} / \mathrm{d}$, respectively; $\mathrm{P}=0.9189)$, parity $(2.39 \pm 0.30$ and $2.06 \pm 0.20$ lactations, respectively; $\mathrm{P}=0.3660)$ and days in milk (195.39 \pm 27.01 and $211.66 \pm 18.32$, respectively; $\mathrm{P}=0.6197$ ). Hair coat types were first phenotypically classified and then genomically confirmed. The author visually classified as phenotypically SLICK those cows with a short, sometimes glossy hair coat all around the body; while the cows with the typical longer Holstein hair coat were considered WT. After following the procedures previously described by Littlejohn et al. (2014), Dr. Melvin Pagán (University of Puerto Rico at Mayagüez) generously provided the genomic classifications for all animals. Cows with a visually intermediate hair coat length were not considered. Cows with contradictory phenotypic and genomic classifications were not evaluated. The day after body weight was recorded by an electronic scale, all cows were restricted in headlocks in the farm's free-stall barn (for daily concentrate feeding), and the following measurements (Figure 1) were obtained: withers height, hip height, thoracic perimeter, barrel, and shoulder to pin bone dis-

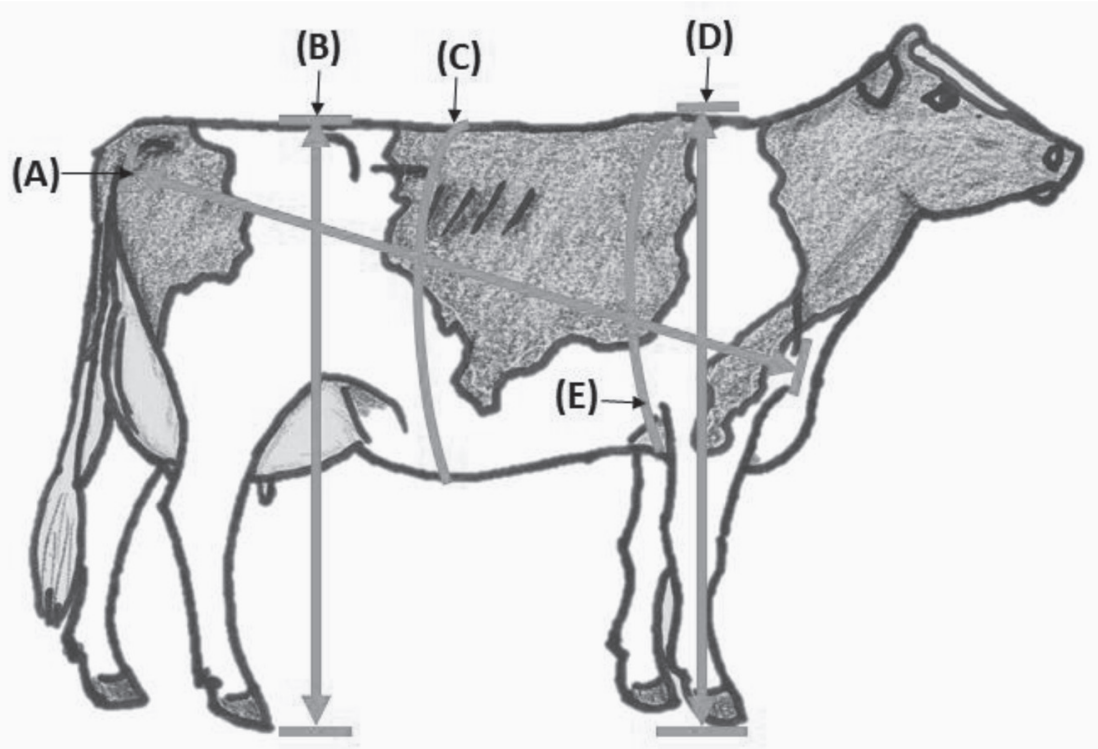

FiguRE 1. Representation of the body dimensions evaluated in slick and wild typehaired Puerto Rican Holstein cows in the present study: (A) shoulder to pin bone distance, (B) hip height, (C) barrel, (D) withers height and (E) thoracic perimeter. Body weight was also recorded, and the body weight / body dimension ratios were calculated. 
tance. Also, the cow's body weight was divided over the respective body dimensions in order to obtain the specific ratios. The withers and hip height were determined by a Measuring Stick (Nasco; Ft. Atkinson, WI $)^{4}$ and the thoracic perimeter, barrel, and shoulder to pin bone distance were recorded by a commercial fiberglass measuring tape (Ace Hardware Corporation, Yauco, PR). All measurements were obtained with the cows standing straight and square on a level surface. During sampling, concentrate feed was offered at the headlock feeder. The dependent variables (body weight, withers height, hip height, thoracic perimeter, barrel, shoulder to pin bone distance, and the ratios of body weight over each body dimension) were evaluated by the GLIMMIX procedure of SAS. Hair coat type was included as a fixed effect in the model, while the cow's identification number was considered the random effect. Significant differences were detected at a $\mathrm{P}<0.05$.

\section{RESULTS AND DISCUSSION}

Table 1 presents the body dimension comparisons between hair coat groups. The SLICK cows presented larger barrels $(236.54 \pm 2.68$ vs. $231.06 \pm 2.29 \mathrm{~cm} ; \mathrm{P}=0.0363)$ and body weight / shoulder to pin bone distance $(3.51 \pm 0.09$ vs. $3.32 \pm 0.08 \mathrm{~kg} / \mathrm{cm} ; \mathrm{P}=0.0218)$ than their WT relatives. However, the opposite was observed in the shoulder to pin bone distance, where SLICK cows were smaller than their WT counterparts (180.07 \pm 1.82 vs. $185.20 \pm 1.56 \mathrm{~cm} ; \mathrm{P}=0.0059)$. No significant differences between hair coat groups were observed in any other of the evaluated variables.

Although not evaluated in the present study, the observed differences in barrel circumference may be explained by differences in feed intake between hair coat groups. It is well known that heat stress limits feed intake in dairy cattle (West, 2003). However, because SLICK cows have a superior thermoregulatory capacity (Castro et al., 2015; Contreras-Correa et al., 2016; Sánchez-Rodríguez et al., 2016; Contreras-Correa et al., 2017; Muñiz-Cruz et al., 2018), a smaller impact on feed intake may be reasonably expected in this group when exposed to tropical weather conditions. The diet of the evaluated cows consisted of limited access to concentrate feed immediately before milking and ad libitum access to tropical grasses the remaining daily period. Therefore, different intakes of concentrate feed are unlikely between hair coat groups because the feed is offered in limited quantities under

${ }^{4}$ Company or trade names in this publication are used only to provide specific information. Mention of a company or trade name does not constitute an endorsement by the Agricultural Experiment Station of the University of Puerto Rico, nor is this mention a statement of preference over other equipment or materials. 


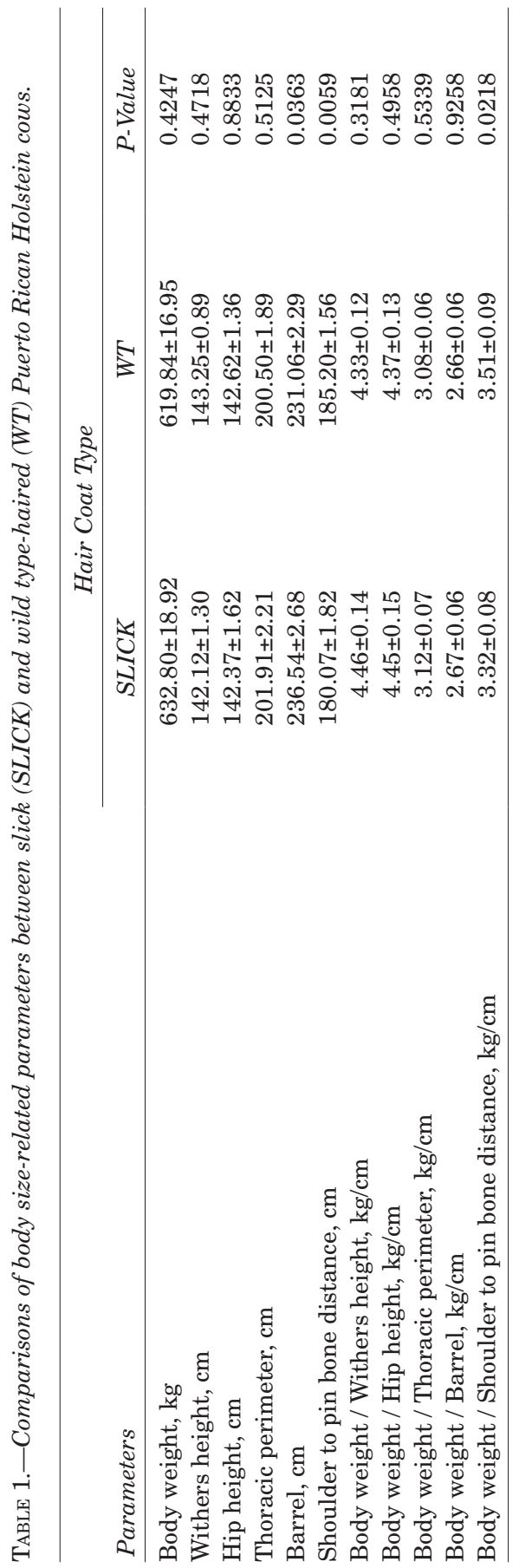


the shade of the barn [which limits heat stress impact, and the first milking occurs early in the morning $(0300 \mathrm{~h})$ when there is no solar radiation] and cows normally show a marked preference for this kind of food. However, when cows are taken to the pasture paddocks (where solar radiation is a major environmental issue in the tropics) it is not uncommon to observe SLICK cows grazing under the sun during the hottest hours of the day; while all their WT relatives rest in the shade, lying in the mud in an attempt to alleviate the negative impacts of heat stress (Sánchez-Rodriquez, 2019). In fact, such differences in intake may help to explain the greater milk production reported in SLICK cows by Delgado et al. (2014) and Contreras-Correa et al. (2016). In order to eat greater amounts of tropical grasses, a larger ruminal capacity is required, since tropical grasses are high in fiber (Stobbs, 1995), including lignin, which is especially high during the dry season (Detmann et al., 2009). In fact, it has been reported that the addition of fiber to the diet of Holstein calves (Khan et al., 2012) and cows (Hale et al., 1940; Dado and Allen, 1995) increases their barrel circumferences and ruminal capacities. Such high lignin content limits fiber digestion in ruminants (Jung, 1987), probably making necessary greater intake to achieve the aforementioned superior milk production. Therefore, a larger dry matter intake of high fiber tropical forages may help to explain the observed differences in barrel dimensions as well as the lack of any difference in body weight between hair coat groups $(\mathrm{P}=0.4247$; Table 1), as a larger barrel may add weight and compensate for the shorter body observed in SLICK cows.

If the proposed effect of a larger ruminal capacity and barrel on the body weight of SLICK cows could be excluded, the observed shorter bodies in this group may indicate differences in mature body size between phenotypes. A previous study from our group (Muñiz-Cruz et al., 2017) observed that from four to 34 months of age, while the WT Puerto Rican Holstein heifers grow in a linear pattern, their SLICK relatives presented a quadratic relation between age and body weight. Normal growth curves in cattle increase at a fast, close to linear rate during the juvenile stage, begin to stabilize as maturity approaches, and remain steady with no further changes during adult life (McDaniel and Legates, 1965; Berry et al., 2005). Thus, in the Muñiz-Cruz et al. (2017) study, by 34 months of age the SLICK heifers may have been approaching the stabilization stage of the curve, while their WT counterparts were still in the fast growing, juvenile stage. Therefore, these results suggested that SLICK heifers may be able to reach maturity earlier and with a smaller body size than the WT ones, supporting the findings of the present study. In fact, Bergmanns (1847; as reviewed by Meiri and Dayan, 2003) stated that animals from the same species 
present a smaller body size when they adapt to the tropics, in comparison to those raised in temperate locations. He explained that a smaller body size implies a larger surface area to body volume ratio, which facilitate heat dissipation under hot environmental conditions. Concurrently, the larger body weight / shoulder to pin bone distance ratio observed in the SLICK cows reflects the previously discussed lack of difference in body weight between hair coat groups and a shorter body.

Having shorter bodies and greater feed intake may result in productive advantages, which support the aforementioned greater milk yields in SLICK than in WT cows (Delgado et al., 2014; Contreras et al., 2016). Since 1966, the University of Minnesota has selected their Holstein cattle in terms of body size, resulting in both small and large sized herds (Mahoney et al., 1986; Yerex et al., 1988; Hansen et al., 1999). When compared, the small sized herd presented lower disease incidence (Mahoney et al., 1986), longer productive lives (Hansen et al., 1999), and greater feed efficiencies (Yerex et al., 1988) than their large-sized counterparts. The concept of "dilution of maintenance effect" establishes that if two cows with similar body weights, but different milk productions, are compared, the one with the larger volume of milk will be more efficient in terms of energy use (VandeHaar and St-Pierre, 2006; Capper et al., 2009; Bauman and Capper, 2010). That is so because cows with similar body sizes will have similar energy requirements for maintenance. But even though a greater milk production implies a greater energy requirement for milk synthesis, the total energy costs per unit of milk produced will be diluted. As previously mentioned, if the assumption of a greater feed intake in SLICK cows is correct, removing the ruminal content may result in a smaller body weight in the SLICK cows. Therefore, the energy requirements for maintenance may be smaller in the SLICK group, since body size directly influences the energy requirements for maintenance (Demment and Van Soest, 1985; Veerkamp, 1988). Taking this into consideration, SLICK cows may be more efficient by both a smaller maintenance requirement and a greater volume of milk produced.

In order to maintain the greater productivity normally reported in SLICK cows (Delgado et al., 2014; Contreras et al., 2016), both a greater feed intake and a greater degree of ruminal fermentation are required. Greater ruminal fermentation has been associated with a larger amount of metabolic heat produced and greater body temperatures in cattle (Russell, 2007). However, several studies from our group have reported lower body temperatures in the SLICK than in the WT cows (Sánchez-Rodríguez et al., 2015; Sánchez-Rodríguez et al., 2016). There may be two possible explanations for this apparent discrepancy. First, the SLICK cows have achieved a series of important adapta- 
tions to tropical weather, including a shorter hair coat (Sánchez, 2019) and larger sweat glands (Contreras-Correa et al., 2017; Muñiz-Cruz et al., 2018), that allow for greater heat dissipation in comparison with WT similar cows. Second, if the author's observations are correct, the SLICK group only eats larger quantities of tropical grasses, but not of concentrate feed. This is important in terms of ruminal heat production because the non-structural carbohydrates (starch) in concentrate feed are easily fermentable in the rumen, allowing large quantities of heat to be released (Alzahal et al., 2011). However, the structural carbohydrates found in forages are slowly and partially fermented in the rumen, resulting in less heat production (Alzahal et al., 2011).

\section{CONCLUSIONS}

Puerto Rican SLICK cows have a shorter and deeper body in comparison with their WT counterparts. These results are consistent with previous findings from our group where SLICK heifers appeared to reach maturity at a smaller body size than the WTs. In the literature there are examples of the multiple productive advantages that small cows have over larger cows. Consequently, future studies should evaluate if such differences in growth trends and body size could affect the animal's productivity in a tropical scenario.

\section{LITERATURE CITED}

Alzahal, O., H. Alzahal, M.A. Steele, M. Van Schaik, I. Kyriazakis, T.F. Duffield and B.W. McBride, 2011. The use of a radiotelemetric ruminal bolus to detect body temperature changes in lactating dairy cattle. J. Dairy Sci. 94: 3568-3574.

Bauman, D. and J. Capper, 2010. Efficiency of dairy production and its carbon footprint. Proc. Florida Ruminant Nutr. Conf., Gainesville, FL. pp 114-125.

Bergmann, C., 1847. Ueber die verhaltnisse der wdrmeokono- mie der thiere zu ihrer grosse. Gottinger studien. 3:595-708.

Berry, D.P., B. Horan and P.G. Dillon, 2005. Comparison of growth curves of three strains of female dairy cattle. Anim. Sci. 80: 151-160.

Capper, J., R. Cady and D. Bauman, 2009. The environmental impact of dairy production: 1944 compared with 2007. J. Anim. Sci. 87: 2160-2167.

Castro, A., G. Muñiz, J. Curbelo, M. Pagán, A. Mesonero, A. de Jesús, N. Lluch and H. Sánchez, 2015. Effect of the environmental conditions over the vaginal temperature and respiration rate on wild type and slick-haired Puerto Rican Jersey cows. Joint Annual Meeting ADSA-ASAS 2015. July 12-16. Orlando, FL.

Contreras-Correa, Z., G. Muñiz-Colón, M. Pagán-Morales, A. Mesonero-Morales, J. Curbelo-Rodríguez and H.L. Sánchez-Rodríguez, 2016. Hematocrit, milk yield, and production related parameters comparisons between slick and wild type-haired Puerto Rican Holstein cows. Joint Annual Meeting, ASAS-ADSA-CSAS-WSASAS. July 1923. Salt Lake City, UT.

Contreras-Correa, Z., N. Peña-Alvarado, W. Torres-Ruiz, J. Almodóvar-Rivera, K. Domenech-Pérez, C. Youngblood, M. Pagán-Morales, A. Mesonero-Morales, J. Curbelo-Rodríguez, P. Randel-Follin, G. Muñiz-Colón, V. Colón-González, Á. JiménezArroyo, G. Jiménez-Arroyo and H. Sánchez-Rodríguez, 2017. Slick-haired Puerto 
Rican Holstein cows have larger sweat glands than their wild type-haired counterparts. ADSA 2017. June 25-28. Pittsburgh, PA.

Dado, R.G. and M.S. Allen, 1995. Intake limitations, feeding behavior, and rumen function of cows challenged with rumen fill from dietary fiber or inert bulk. J. Dairy Sci. 78: 118-133.

Delgado, R., G. Colón, Z. Crespo, V. Colón, P. Cordero, G. Vargas, E. Lozada, E. Arcelay, C. Cabrera, E. Riquelme, G. Muñiz, A. de Jesus, N. Lluch and H. Sánchez, 2014. Asociación entre raza, tipo de pelo y producción de leche en vacas lecheras en Puerto Rico. Reunión Científica de la Sociedad Puertorriqueña de Ciencias Agrícolas. Rincón of the Seas. November, 2014. Rincón, PR.

Demment, M.W. and P.J. Van Soest, 1985. A nutritional explanation for body-size patterns of ruminant and nonruminant herbivores. Am. Nat. 125: 641-672.

Detmann, E., M.F. Paulino, H.C. Mantovani, S.C. Valadares-Filho, C.B. Sampaio, M.A. Souza, I. Lazzarini and K.S.C. Detmann, 2009. Parameterization of ruminal fibre degradation in low-quality tropical forage using Michaelis-Menten kinetics. Liv. Sci. 126: 136-146.

Hale, E.B., C.W. Duncan and C.F. Huffman, 1940. Rumen digestion in the bovine with some observations on the digestibility of alfalfa hay. J. Dairy Sci. 23: 953-967.

Hansen, L., J. Cole, G. Marx and A. Seykora, 1999. Productive life and reasons for disposal of Holstein cows selected for large versus small body size. J. Dairy Sci. 82: 795-801.

Jung, H.G., 1987. Forage lignins and their effects on fiber digestibility. Agron. J. 81: 33-38.

Khan, M.A., D.M. Weary, D.M. Veira and M.A.G. von Keyserlingk, 2012. Postweaning performance of heifers provided hay during the milk feeding period. J. Dairy Sci. 95: 3970-3976.

Littlejohn, M.D., K.M. Henty, K. Tiplady, T. Johnson, C. Harland, T. Lopdell, R.G. Sherlock, W. Li, S.D. Lukefahr, B.C. Shanks, D.J. Garrick, R.G. Snell, R.J. Spelmanand S.R. Davis, 2014. Functionally reciprocal mutations of the prolactin signalling pathway define hairy and slick cattle. Nature Communications. 5: 1-8.

Mahoney, C., L. Hansen, C. Young, G. Marx and J. Reneau, 1986. Health care of Holsteins selected for large or small body size. J. Dairy Sci. 69: 3131-3139.

McDaniel, D. and J.E. Legates, 1965. Associations between body weight predicted from heart girth and production. J. Dairy Sci. 48: 947-956.

Meiri, S. and T. Dayan, 2003. On the validity of Bergmann's rule. J. Biogeography. 30: 331-351.

Muñiz-Cruz, J.M., G.C. Muñiz-Colón, P.F. Randel-Folling, C.J. Cabrera-Cabrera, C. Youngblood, K.I. Domenech-Pérez and H.L. Sánchez-Rodríguez, 2017. Monthly body weight change in wild type and slick-haired post-weaned Puerto Rican Holstein heifers. ADSA 2017. June 25-28. Pittsburgh, PA.

Muñiz-Cruz, J., N. Peña-Alvarado, W. Torres-Ruiz, J. Almodóvar-Rivera, K. DomenechPérez, Z. Contreras-Correa, G. Muñiz-Colón, A. Cortés-Arocho, J. Santiago-Rodríguez, S. Ruiz-Ríos, G. Soriano-Varela, N. Cortés-Viruet, A. Jiménez-Arroyo, G. Jiménez-Arroyo and H. Sánchez-Rodríguez, 2018. Sweat gland cross-sectional cut areas comparisons between slick and wild type-haired Holstein and Senepol cows in Puerto Rico. ADSA 2018. June 24-27. Knoxville, TN.

Russell, J.B., 2007. Can the heat of ruminal fermentation be manipulated to decrease heat stress? Proceedings of the 22nd Annual Southwest Nutrition and Management Conference 22: 109-115.

Sánchez, H., A. Castro, M. Pagán, J. Curbelo, A. Mesonero and G. Muñiz, 2015. Effects of the thermal humidity index on vaginal temperature of slick- and wild type-haired Puerto Rican Holstein cows. Joint Annual Meeting ADSA-ASAS 2015. July 12-16. Orlando, FL.

Sánchez-Rodríguez, H.L., 2019. Revisión histórica y científica sobre el desarrollo de la ganadería de leche en Puerto Rico con énfasis en el ganado pelón. J. Agric. Univ. P. R. 103(1): 107-139.

Sánchez-Rodríguez, H., Z. Contreras-Correa, M. Pagán-Morales, J. Curbelo-Rodríguez, A. Mesonero-Morales, C. Cabrera-Cabrera and G. Muñiz-Colón, 2016. Associations 
between the environmental conditions and vaginal temperature in wild type and slick-haired Puerto Rican Holstein cows. Joint Annual Meeting, ASAS-ADSACSAS-WSASAS. July 19-23. Salt Lake City, UT.

Silanikove, N., 2000. Effects of heat stress on the welfare of extensively managed domestic ruminants. Livest. Prod. Sci. 67: 1-18.

Stobbs, T.H., 1995. Factors limiting the nutritional value of grazed tropical pastures for milk and beef production. Tropical Grasslands. 9(2): 141-150.

Veerkamp, R., 1998. Selection for economic efficiency of dairy cattle using information on live weight and feed intake: A review. J. Dairy Sci. 81: 1109-1119.

West, J.W., 2003. Effects of heat-stress on production in dairy cattle. J. Dairy Sci. 86: 2131-2144.

Yerex, R., C. Young, J. Donher and G. Marx, 1988. Effects of selection for body size on feed efficiency and size of Holsteins. J. Dairy Sci. 71: 1355-1360.

VandeHaar, M. and N. St-Pierre. 2006. Major advances in nutrition: relevance to the sustainability of the dairy industry. J. Dairy Sci. 89: 1280-1291. 